American Journal of Environmental Sciences 4 (6): 631-637, 2008

ISSN 1553-345X

(C) 2008 Science Publications

\title{
Tropospheric Ozone Effects on the Productivity of Some Crops in Central Saudi Arabia
}

\author{
${ }^{1}$ Akram Ali, ${ }^{1}$ Ahmad Alfarhan, ${ }^{2}$ Ernest Robinson, ${ }^{1}$ Nagat Bokhari, \\ ${ }^{3}$ Khaled Al-Rasheid and ${ }^{3}$ Saleh Al-Quraishy \\ ${ }^{1}$ Department of Botany and Microbiology, College of Science, King Saud University, \\ Riyadh 11451, PO Box: 2455, KSA \\ ${ }^{2}$ King Khalid Wildlife Research Centre, Thumamah, C/o. National Commission for Wildlife \\ Conservation and Development, P.O. Box 61681, Riyadh 11575, KSA \\ ${ }^{3}$ Department of Zoology, College of Science, King Saud University, Riyadh 11451, P.O. Box: 2455, KSA
}

\begin{abstract}
This study was conducted to evaluate damaging degree of ambient ozone $\left(\mathrm{O}_{3}\right)$ levels in certain economically important crops in typical areas of the central KSA (Riyadh). Daily mean ozone concentrations were recorded by portable $\mathrm{O}_{3}$ analyzers in the center of Batha, Naseem, Oleya and Industrial City, from the beginning of October, 2006 to middle of June, 2007. Maseef area was used as control because it is receiving fewer pollutants $\left(\mathrm{O}_{3}\right.$ levels less than $\left.40 \mathrm{~nL} \mathrm{~L}^{-1}\right)$. Selected crops grown in pots were exposed to short-term of pollution at defined localities. These crops include Triticum aestivum L. cv. Giza 68 (wheat), Vicia faba L. cv. Lara, (broad bean), Phaseolus vulgaris L. cv. Giza 3 (kidney bean) and Pisum sativum L. cv. Perfection (pea). The exposure indicators of them are length, injury symptoms, biomass and yield. The maximum values of daily $\mathrm{O}_{3}$ were $125 \mathrm{~nL} \mathrm{~L}^{-1}, 77 \mathrm{~nL} \mathrm{~L}^{-1}, 95$ $\mathrm{nL} \mathrm{L}{ }^{-1}$ and $166 \mathrm{~nL} \mathrm{~L}^{-1}$, in all the four studied areas, respectively in mid June, 2007. Results showed that the estimated yield losses varied in all four studied areas, being 35, 9, 39 and $46 \%$, respectively for wheat; being 16, 13, 21 and 33\%, respectively for broad bean; being 22, 20, 28 and $45 \%$, respectively for kidney bean and being 5,3,14 and 30\%, respectively for pea. This research recommended that these plant species can be used to give bio-indicator significance to assess ambient ozone impacts of different examined areas in KSA.
\end{abstract}

Key words: $\mathrm{O}_{3}$-Pollution, short-term exposure, crops, growth, reduction

\section{INTRODUCTION}

The climatic record of the Middle East region for the past five years showed that there were fluctuations in the temperature and a decrease in rainfall over large portions ${ }^{[1]}$. Human activities in Saudi Arabia such as burning fossil fuels and changes in land use that modify the global climate with temperature rise projected for the next 100 years could affect the human welfare and the environment. In the 21 st century, warming trend and changes in precipitation patterns are expected to continue along with a rise in sea level and increased frequency of extreme weather events ${ }^{[26]}$.

The $\mathrm{O}_{3}$ concentration in the normal range is $10-30$ $\mathrm{nL} \mathrm{L}^{-1}[25]$. By rising temperature, its levels could reach above the natural ones. KSA has high levels of this gas during hot and sunny days when poor circulation occurs in the atmospheric boundary layer. In the mid-latitudes, such conditions are typical of the summer season and are associated with anticyclonic weather [22, 28]. However, the $\mathrm{O}_{3}$ pollution in Saudi Arabia is a matter of concern to all environmentalists of this region.

Ozone potentiality to injure vegetation has been known for over 50 years ${ }^{[16]}$. It is clear that ambient $\mathrm{O}_{3}$ can cause visible leaf injury, growth and yield reductions and alter sensitivity to biotic and abiotic stresses ${ }^{[15]} \cdot \mathrm{O}_{3}$ is indicated as the main culprit for economic crop damage caused by air pollution in the USA and probably causes more damage to vegetation than all other pollutants combined [21]. Economic involvement of these effects may be important ${ }^{[20,28]}$. An understanding of exposure/response requires three types of information: a measure of plant response ${ }^{[21]}$; an index describing pollutant exposure ${ }^{[19]}$; and a

Corresponding Author: Akram Ali, Department of Botany, Faculty of Science, Zagazig University, Zagazig, Egypt Tel: 00966557554020 Fax: 0096614675833 
mathematical function that relates plant response to exposure $^{[34]}$.

The accurate estimation of crop yield loss is essential for producing useful measures of the economic effect of pollutants ${ }^{[37]}$. A number of experimental approaches have been used to assess the effects of chronic exposure of $\mathrm{O}_{3}$ and crop response ${ }^{[27]}$. Ground surveys of vegetation in the vicinities of the monitoring sites have been done and candidates for bioindicators for ozone have been identified ${ }^{[28,29]}$. The open top chamber (OTC) method is the most widely used $^{[1,2,3,4,30]}$ to evaluate the degree of damage by $\mathrm{O}_{3}$. On the other hand, Nali, et al. ${ }^{[32]}$ studied its effect on some economic crops productivity in ambient plots. Forty-eight experts from several European countries participated in the exercises and assessed visible symptoms of ozone injury both in OTC (Lattecaldo) and under open field (Moggio) conditions ${ }^{[10]}$. The most comprehensive series of experiments on the relationship between $\mathrm{O}_{3}$ exposure and crop yield began in 1980, when the National Crop Assessment Network (NCLAN) was established in the USA ${ }^{[20]}$. Muzikaa et al. [31] also studied many variable representing the combined effect of $\mathrm{O}_{3}, \mathrm{SO}_{2}$ and $\mathrm{NO}_{2}$ and was negatively correlated with both Picea abies and Fagus sylvatica growth.

Short-term $\mathrm{O}_{3}$ exposure is demonstrated to be appropriate for several economically important agricultural species and also for trees and natural vegetation ${ }^{[23]}$. While, cultivated plants and middaylight hours were the best living organisms and time respectively to evaluate the biomass responses to all critical levels ${ }^{[23]}$. Research has shown that considerable inter- and intra-species variation exists, some of which may result from different environmental conditions under which the experiments were performed, such as $\mathrm{O}_{3}$ concentration ${ }^{[13]}$.

This study focuses on 1) monthly monitoring of the concentrations of $\mathrm{O}_{3}, \mathrm{SO}_{2}, \mathrm{NO}_{2}$ in five areas (Maseef, Batha, Naseem, Oleya and Industrial City) of the SA; 2) $\mathrm{O}_{3}$ effects on studied crops (wheat, broad bean, kidney bean, pea) biomass and morphology; 3) assessing yield reductions of these crops in response to $\mathrm{O}_{3}$.

\section{MATERIALS AND METHODS}

Collecting climate data: Climate monitored at five localities in Riyadh: Maseef, Batha, Naseem, Olaea and Industrial City. Data were collected from the beginning of October 2006 to the end of June 2007. Monthly air temperature, rain fall, relative humidity and wind speed were recorded. Concentrations of studied gases were measured daily at 10AM and $5 \mathrm{PM}$ using $\mathrm{O}_{3}, \mathrm{SO}_{2}, \mathrm{NO}_{2}$ meters, Graywolf Sensing Solutions, Sweden. These instruments have barometric compensation and internal calibration systems, which perform daily zero/span checks. The means of 7 hours daily (applied to the solar time) and of 30 days monthly were calculated and expressed in ppb $\left(\mathrm{nL} \mathrm{L}^{-1}\right)$. All $\mathrm{O}_{3}, \mathrm{SO}_{2}, \mathrm{NO}_{2}$ concentrations were stored in special files in a $\mathrm{PC}$.

Plantation, treatments and measurements: Seeds of Triticum aestivum L. cv. Giza 68 (wheat), Vicia faba L. cv. Lara, (broad bean), Phaseolus vulgaris L. cv. Giza 3 (kidney bean) and Pisum sativum L. cv. Perfection (pea) were planted in pots at the Botany and Microbiology Department, Faculty of Science, King Saud University during the last week of November 2007 under controlled conditions from suitable soil and irrigation. These plants were left until reaching good vegetative growth $(20-25 \mathrm{~cm}$ length) then, total number of plants reduced to be 10 in each pot. All pots were transferred to test polluted localities (Maseef, Batha, Naseem, Olaea and Industrial City). Maseef area used as a control.

The biomass was determined when green harvest done. The fresh weights of total leaves, stems and roots were weighed at the end of the growing season, April 2007. At this time the individual plant length was measured with a plastic ruler at the end of growing season. Individual leaf area per plant was measured. A week after seed formation, green harvest was performed. The leaves were divided into the following categories; health; (green), senescent (yellowing) and injured. Subsequently, the proportion of leaves in each of the three categories was calculated per pot. A dry harvest was carried out in April 2007 when seeds were brown and plants carried loosely seeds, then seeds characters were determined.

Statistical analysis: Statistical analyses were carried out using the SPSS BASE 10.0 (SPSS Inc., Chicago, IL) packages. Data were tested by ANOVA. LSD at $\mathrm{p} \leq 0.05$ was applied to detect the effect of $\mathrm{O}_{3}$ short-term critical level on some economic crops. Mean and variance separation between different localities were calculated by using the means of individual measurements. 


\section{RESULTS AND DISCUSSION}

Climatic distribution: Mean values of meteorological parameters in Riyadh city, KSA (2006/2007) were recorded in Table 1. They showed low values during months of January; June; October, May and June; and October, November and June for air temperature, humidity, wind velocity and rain-fall, respectively. While an increase in June, January, November and January for air temperature, humidity, wind velocity and rain-fall, respectively. Gradual decrease in the air temperature occur, reaching to a minimum of $18^{\circ} \mathrm{C}$ in January followed by gradual increase reaching to a maximum of $42^{\circ} \mathrm{C}$ in June. On the other hand, the gradual decrease in humidity and rain-fall tend to be in summer months, while wind velocity vary throughout the year. Monthly and daily mean values of gases' $\left(\mathrm{O}_{3}\right.$, $\mathrm{SO}_{2}$ and $\mathrm{NO}_{2}$ ) concentration $\left(\mathrm{nL} \mathrm{L}^{-1}\right)$ in Riyadh city, KSA during the growth period of studied crops (2006/2007) were listed in Tables 2, 3. The results showed that $\mathrm{O}_{3}$ levels are higher in the urban (Industrial City, Batha and Olea) than in the suburban (Naseem) or surrounding rural sites (Maseef), because the presence of high concentrations of $\mathrm{NO}$ in the city centre is a major cause of destroying $\mathrm{O}_{3}{ }^{[8]}$. When the behavior of the localities is compared, it was observed that monthly values captured at Industrial City were significantly high (Table 2). The greatest values follow the highest solar radiation, which is the basis of the photochemical reactions, involving the components of vehicle emissions and other sources. This behavior is typical of the urban areas where $\mathrm{O}_{3}$ quickly increases during the day through the photochemical cycle and just as quickly decreases in the reversible reaction $\mathrm{NO}+\mathrm{O}_{3}=\mathrm{NO}_{2}+\mathrm{O}_{2}$ ${ }^{[8]}$. Industrial City showed the highest $\mathrm{O}_{3}$ values at the mid-day. In every examined day, it is recorded higher concentrations than the other localities, showing values ranging from $43-167 \mathrm{~nL} \mathrm{~L}^{-1}$. This site observed the greatest hourly average of $185 \mathrm{~nL} \mathrm{~L}^{-1}$, recorded on 8 June 2007. This is largely believed to be from horizontal air transport, high solar radiation (temperature and light), heavy traffic and a subsequent accumulation of photochemical products, which is common in all big cities ${ }^{[14]}$. This value is above the threshold for public warning (ca. $184 \mathrm{ppb}$ ). Saturday recorded the highest ozone levels due to the heavy traffic (Table 3).

All studied localities of the Riyadh city showed higher values of $\mathrm{O}_{3}, \mathrm{SO}_{2}$ and $\mathrm{NO}_{2}$ levels except Maseef. The data in Table 3 ensured that weekend-work days had less effect as reported in other cities such as Rome [11] and the metropolitan area of New Jersey, New York City ${ }^{[8]}$.
Table 1: Mean values of meteorological parameters in Riyadh city, KSA (2006/2007)

\begin{tabular}{lllll}
\hline & \multicolumn{3}{l}{ Air temperature Humidity } \\
$(\%)$ & $\begin{array}{l}\text { Wind velocity Rain- } \\
\left(\mathrm{km} \mathrm{h}^{-1}\right)\end{array}$ & fall $(\mathrm{mm})$ \\
\hline Months & $\left({ }^{\circ} \mathrm{C}\right)$ & 30 & 6 & 0 \\
\hline October 2006 & 39 & 33 & 9 & 0 \\
November 2006 & 30 & 35 & 8 & 3.12 \\
December 2006 & 22 & 36 & 7 & 18.8 \\
January 2007 & 18 & 35 & 8 & 12.6 \\
February 2007 & 20 & 30 & 7 & 13.6 \\
March 2007 & 32 & 30 & 8 & 1.78 \\
April 2007 & 36 & 28 & 6 & 0.55 \\
May 2007 & 41 & 22 & 6 & 0 \\
June 2007 & 42 & & &
\end{tabular}

Table 2: Monthly mean values of gases concentration $\left(\mathrm{nL} \mathrm{L}^{-1}\right)$ in Riyadh city, KSA during the growth period of studied crops $(2006 / 2007)$

\begin{tabular}{|c|c|c|c|}
\hline $\begin{array}{l}\text { Localities } \\
\text { /Months }\end{array}$ & $\begin{array}{l}\mathrm{O}_{3} \\
\text { concentrations }\end{array}$ & $\begin{array}{l}\mathrm{SO}_{2} \\
\text { concentrations }\end{array}$ & $\begin{array}{l}\mathrm{NO}_{2} \\
\text { concentrations }\end{array}$ \\
\hline \multicolumn{4}{|l|}{ Maseef } \\
\hline October 2006 & 38 & 13 & 12 \\
\hline November 2006 & 33 & 13 & 12 \\
\hline December 2006 & 29 & 13 & 12 \\
\hline January 2007 & 25 & 11 & 11 \\
\hline February 2007 & 26 & 10 & 11 \\
\hline March 2007 & 34 & 11 & 12 \\
\hline April 2007 & 35 & 13 & 11 \\
\hline May 2007 & 36 & 12 & 13 \\
\hline \multirow{2}{*}{\multicolumn{4}{|c|}{ Batha }} \\
\hline & & & \\
\hline October 2006 & 95 & 23 & 22 \\
\hline November 2006 & 82 & 21 & 20 \\
\hline December 2006 & 57 & 15 & 16 \\
\hline January 2007 & 55 & 14 & 15 \\
\hline February 2007 & 66 & 10 & 14 \\
\hline March 2007 & 87 & 10 & 15 \\
\hline April 2007 & 94 & 21 & 16 \\
\hline May 2007 & 95 & 21 & 18 \\
\hline June 2007 & 125 & 22 & 19 \\
\hline \multicolumn{4}{|l|}{ Naseem } \\
\hline October 2006 & 64 & 18 & 22 \\
\hline November 2006 & 64 & 18 & 22 \\
\hline December 2006 & 46 & 18 & 15 \\
\hline January 2007 & 33 & 17 & 15 \\
\hline February 2007 & 33 & 10 & 13 \\
\hline March 2007 & 46 & 12 & 14 \\
\hline April 2007 & 58 & 13 & 16 \\
\hline May 2007 & 62 & 14 & 19 \\
\hline June 2007 & 77 & 15 & 20 \\
\hline \multicolumn{4}{|l|}{ Olea } \\
\hline October 2006 & 82 & 24 & 26 \\
\hline November 2006 & 60 & 23 & 25 \\
\hline December 2006 & 44 & 23 & 22 \\
\hline January 2007 & 45 & 16 & 15 \\
\hline February 2007 & 55 & 16 & 17 \\
\hline March 2007 & 79 & 16 & 18 \\
\hline April 2007 & 93 & 18 & 19 \\
\hline May 2007 & 95 & 19 & 23 \\
\hline June 2007 & 95 & 29 & 27 \\
\hline \multicolumn{4}{|l|}{ Industrial city } \\
\hline October 2006 & 115 & 29 & 26 \\
\hline November 2006 & 85 & 24 & 23 \\
\hline December 2006 & 55 & 20 & 22 \\
\hline January 2007 & 50 & 15 & 21 \\
\hline February 2007 & 52 & 20 & 24 \\
\hline March 2007 & 77 & 25 & 25 \\
\hline April 2007 & 89 & 33 & 35 \\
\hline May 2007 & 120 & 35 & 33 \\
\hline June 2007 & 166 & 41 & 32 \\
\hline
\end{tabular}


Am. J. Environ. Sci., 4 (6): 631-637, 2008

Table 3: Daily mean values of gases concentration $\left(\mathrm{nL} \mathrm{L}^{-1}\right)$ in Riyadh city, KSA during the growth period of studied crops $(2006 / 2007)$

\begin{tabular}{llll}
\hline $\begin{array}{l}\text { Localities } \\
\text { /Days }\end{array}$ & $\begin{array}{l}\mathrm{O}_{3} \\
\text { concentrations }\end{array}$ & $\begin{array}{l}\mathrm{SO}_{2} \\
\text { concentrations }\end{array}$ & $\begin{array}{l}\mathrm{NO}_{2} \\
\text { concentrations }\end{array}$ \\
\hline Saturday & 178 & 43 & 40 \\
Sunday & 135 & 33 & 32 \\
Monday & 131 & 33 & 33 \\
Tuesday & 129 & 32 & 31 \\
Wednesday & 130 & 30 & 33 \\
Thursday & 86 & 17 & 11 \\
Friday & 54 & 11 & 10 \\
\hline
\end{tabular}

1979). The concentrations of $\mathrm{O}_{3}$ during the work days were very similar except Saturday. Some of the results are not shown, as no statistically significant differences. According to the literature ${ }^{[23]}$, the $\mathrm{O}_{3}$ levels observed in Riyadh city can also affect plants. Industrial city often showed continuous exceedances for the entire hot month, in May, June and October ${ }^{[32]}$. Ozone in high levels during these three summer months are quite common in many Mediterranean countries, with frequent values up to $200 \mathrm{nLL}^{-1} \mathrm{~h}^{[17]}$. Concentrations of $\mathrm{SO}_{2}$ and $\mathrm{NO}_{2}$ in Maseef recorded close values during months of the study, while in other localities recorded high variations ranged between $10-41 \mathrm{nLL}^{-1}$ and between $13-35 \mathrm{nLL}^{-1}$ for $\mathrm{SO}_{2}$ and $\mathrm{NO}_{2}$, respectively (Table 2). Daily concentrations of $\mathrm{SO}_{2}$ and $\mathrm{NO}_{2}$ often showing maximum values above 43 and $40 \mathrm{nLL}^{-1}$, respectively during Saturday (Table 3 ).

Effect of ozone on studied crops: Short-term ozone impacts on some characters of wheat, broad bean, kidney bean and pea plants are shown in Tables 4-8. In order to evaluate the production losses of the most important crops in Riyadh, the authors considered their distribution and a set of exposure on morphology, biomass, yield response relationships of four economic crops as proposed by UNECE (United Nation Economic Commission for Europe) and US-NCLAN. Reduction in length of wheat plants subjected to climatic changes at Industrial city reached to $28 \%$, while it is 13, 9 and 15 at Batha, Naseem and Oleya respectively (Table 4). Kidney bean and pea lengths were reduced in highly polluted localities but nonsignificant. The localities chosen at Batha and Naseem recorded non-significant reduction in length of broad bean. In addition, the probable economic loss of broad bean for Oleya and Industrial city was estimated. Naseem station recorded no significant difference in leaf area of wheat, while other stations were significant in comparison with Maseef Station (Table 5). Significant decreases were recorded in the leaf area of broad bean, kidney bean and pea plants grown in pots at
Table 4: Effect of $\mathrm{O}_{3}$ on final lengths $(\mathrm{cm})$ of wheat, broad bean, kidney bean and pea plants grown in pots at five localities, Riyadh, KSA (2006/2007)

\begin{tabular}{lllll}
\hline Localities & $\begin{array}{l}\text { Wheat } \\
\text { length/pot }\end{array}$ & $\begin{array}{l}\text { Broad bean } \\
\text { length/pot }\end{array}$ & $\begin{array}{l}\text { Kidney bean } \\
\text { length/pot }\end{array}$ & $\begin{array}{l}\text { Pea } \\
\text { length/pot }\end{array}$ \\
\hline Maseef & 139.1 & 89.1 & 64.1 & 44.0 \\
Batha & 121.2 & 77.5 & 56.2 & 36.2 \\
Naseem & 128.4 & 75.9 & 52.1 & 35.3 \\
Olaea & 123.2 & 66.0 & 45.6 & 33.2 \\
Industrial City & 108.6 & 57.9 & 43.9 & 32.2 \\
LSD $(\mathrm{p} \leq 0.05)$ & 11.1 & 14.8 & 12.3 & 21.2 \\
\hline
\end{tabular}

Table 5: Effect of $\mathrm{O}_{3}$ on final leaf areas $\left(\mathrm{cm}^{2}\right)$ of wheat, broad bean, kidney bean and pea plants grown in pots at five localities, Riyadh, KSA (2006/2007)

\begin{tabular}{lllll}
\hline Localities & $\begin{array}{l}\text { Wheat leaf } \\
\text { area/plant }\end{array}$ & $\begin{array}{l}\text { Broad bean } \\
\text { leaf area/plant }\end{array}$ & $\begin{array}{l}\text { Kidney bean } \\
\text { leaf area/plant }\end{array}$ & $\begin{array}{l}\text { Pea leaf } \\
\text { area/plant }\end{array}$ \\
\hline Maseef & 7.2 & 4.7 & 4.1 & 3.6 \\
Batha & 4.4 & 3.1 & 3.1 & 3.2 \\
Naseem & 6.2 & 3.5 & 3.3 & 3.3 \\
Olaea & 4.6 & 2.8 & 3.0 & 3.4 \\
Industrial city & 3.5 & 2.4 & 2.5 & 2.5 \\
LSD (p $\leq 0.05)$ & 2.1 & 1.1 & 1.2 & 0.5 \\
\hline
\end{tabular}

Oleya and Industrial city, Industrial city and Industrial city respectively. Evaluation of $\mathrm{O}_{3}$ short-term damage to biomass of the studied economic crops for the Riyadh Region, recorded a little variation between examined localities (Table 6). The $\mathrm{O}_{3}$ concentrations caused quantitative biomass losses of wheat total biomass varying from $6 \%$ for Batha, $5 \%$ for Naseem, $13 \%$ for Oleya and $16 \%$ for Industrial city. The estimated of high biomass loss varied from $6 \%$ for broad bean to $7 \%$ for pea, while reached $4 \%$ for kidney bean. Effect of $\mathrm{O}_{3}$ on a number of leaf categories such as healthy (He), senescence (Se), injury (In) of wheat, broad bean, kidney bean and pea plants grown in pots at five localities (2006/2007)are summarized in Table 7.

At the end of growing season of wheat and broad bean, number of injured leaves of wheat was increased by $27 \%$ at Batha, by $20 \%$ at Naseem, by $11 \%$ at Oleya and by $43 \%$ at Industrial city, while this number for broad bean was $33 \%$ at Batha, $22 \%$ at Naseem, $42 \%$ at Oleya and $33 \%$ at Industrial city. On the other hand, number of healthy leaves of kidney bean was decreased at Batha by $6 \%$, at Naseem by $6 \%$, at Oleya by $33 \%$ and at Industrial city by $50 \%$, while this number for pea was $8 \%$ at Batha, $13 \%$ at Naseem, $50 \%$ at Oleya and length $59 \%$ at Industrial city. Generally, quantitative yield loss of studied economic crops was exceeded at all the localities except Maseef (Table 8). Due to the highest levels of $\mathrm{O}_{3}$ in all studied areas, the big loss reached to $46 \% 5 \mathrm{n}$ case of wheat in Industrial city, followed by Oleya (39\%). Wheat showed that varied yield losses in all studied areas being 35, 9, 39 and 46\% in Batha, Naseem, Olea and Industrial city, respectively. In Maseef, the number of wheat seeds 
Am. J. Environ. Sci., 4 (6): 631-637, 2008

Table 6: Effect of $\mathrm{O}_{3}$ on biomass (gm) of wheat, broad bean, kidney bean and pea plants grown in pots at five localities, Riyadh, KSA $(2006 / 2007)$

\begin{tabular}{|c|c|c|c|c|c|c|c|c|c|c|c|c|}
\hline \multirow[b]{2}{*}{ Localities } & \multicolumn{3}{|c|}{ Wheat biomass/pot } & \multicolumn{3}{|c|}{ Broad bean biomass/pot } & \multicolumn{3}{|c|}{ Kidney bean biomass/pot } & \multicolumn{3}{|c|}{ Pea biomass/pot } \\
\hline & shoot & root & total & shoot & root & total & shoot & root & total & shoot & root & total \\
\hline Maseef & 23.9 & 4.1 & 28.0 & 65.8 & 13.5 & 79.3 & 54.4 & 11.0 & 65.4 & 44.5 & 12.2 & 56.7 \\
\hline Batha & 22.6 & 3.7 & 26.3 & 64.2 & 11.7 & 75.9 & 54.1 & 10.1 & 64.2 & 43.5 & 10.1 & 53.6 \\
\hline Naseem & 23.2 & 3.5 & 26.7 & 64.5 & 12.2 & 76.7 & 54.1 & 10.2 & 64.3 & 43.7 & 11.2 & 54.9 \\
\hline Olaea & 22.2 & 2.6 & 24.8 & 64.3 & 11.3 & 75.6 & 54.0 & 9.8 & 63.8 & 43.8 & 10.1 & 53.9 \\
\hline Industrial City & 22.1 & 2.1 & 24.2 & 63.7 & 10.6 & 74.3 & 53.4 & 9.0 & 62.4 & 43.0 & 10.0 & 53.0 \\
\hline $\operatorname{LSD}(\mathrm{p} \leq 0.05)$ & 1.1 & 1.2 & 0.6 & 0.8 & 0.7 & 0.5 & 0.3 & 0.9 & 1.7 & 4.5 & 0.5 & 1.8 \\
\hline
\end{tabular}

Table 7: Effect of $\mathrm{O}_{3}$ on number of leaf categories: healthy (He), senescence (Se), injury (In) of wheat, broad bean, kidney bean and pea plants grown in pots at five localities, Riyadh, KSA (2006/2007)

\begin{tabular}{|c|c|c|c|c|c|c|c|c|c|c|c|c|}
\hline \multirow[b]{2}{*}{ Localities } & \multicolumn{3}{|c|}{$\begin{array}{l}\text { Wheat Leaf } \\
\text { categories Number/pot }\end{array}$} & \multicolumn{3}{|c|}{$\begin{array}{l}\text { Broad bean Leaf } \\
\text { categories Number/pot }\end{array}$} & \multicolumn{3}{|c|}{$\begin{array}{l}\text { Kidney bean Leaf } \\
\text { categories Number/pot }\end{array}$} & \multicolumn{3}{|c|}{$\begin{array}{l}\text { Pea Leaf categories } \\
\text { Number/pot }\end{array}$} \\
\hline & $\mathrm{He}$ & $\mathrm{Se}$ & In & $\mathrm{He}$ & $\mathrm{Se}$ & In & $\mathrm{He}$ & $\mathrm{Se}$ & In & $\mathrm{He}$ & $\mathrm{Se}$ & In \\
\hline Maseef & 24.0 & 5.0 & 8.0 & 35.0 & 3.0 & 7.0 & 36.0 & 6.0 & 6.0 & 27.0 & 3.0 & 7.0 \\
\hline Batha & 20.0 & 7.0 & 11.0 & 31.0 & 4.0 & 10.0 & 34.0 & 7.0 & 8.0 & 25.0 & 3.0 & 10.0 \\
\hline Naseem & 23.0 & 4.0 & 10.0 & 33.0 & 3.0 & 9.0 & 34.0 & 5.0 & 9.0 & 24.0 & 4.0 & 10.0 \\
\hline Olaea & 21.0 & 7.0 & 9.0 & 27.0 & 6.0 & 12.0 & 27.0 & 8.0 & 13.0 & 18.0 & 5.0 & 15.0 \\
\hline Industrial City & 16.0 & 7.0 & 14.0 & 23.0 & 7.0 & 15.0 & 24.0 & 12.0 & 12.0 & 17.0 & 5.0 & 18.0 \\
\hline LSD $(p \leq 0.05)$ & 6.6 & 2.7 & 3.2 & 4.1 & 2.5 & 3.7 & 4.3 & 5.7 & 2.4 & 4.5 & 1.1 & 4.1 \\
\hline
\end{tabular}

Table 8: Effect of $\mathrm{O}_{3}$ on seeds number and seeds yield (gm) of wheat, broad bean, kidney bean and pea plants grown in pots at five localities, Riyadh, KSA (2006/2007).

\begin{tabular}{|c|c|c|c|c|c|c|c|c|}
\hline \multirow[t]{2}{*}{ Localities } & \multicolumn{2}{|c|}{ Wheat Seeds/pot } & \multicolumn{2}{|c|}{ Broad bean seeds/pot } & \multicolumn{2}{|c|}{ Kidney bean seeds/pot } & \multicolumn{2}{|c|}{ Pea seeds/pot } \\
\hline & number & yield & number & yield & number & yield & number & yield \\
\hline Maseef & 3502 & 77.5 & 657 & 88.5 & 365 & 54.3 & 575 & 59.9 \\
\hline Batha & 3011 & 57.3 & 417 & 76.5 & 284 & 44.4 & 444 & 57.3 \\
\hline Naseem & 3123 & 71.2 & 409 & 78.5 & 314 & 45.3 & 477 & 58.4 \\
\hline Olaea & 2811 & 55.6 & 403 & 73.2 & 247 & 42.5 & 428 & 52.5 \\
\hline Industrial City & 2802 & 53.1 & 333 & 66.4 & 219 & 37.4 & 361 & 46.1 \\
\hline LSD $(p \leq 0.05)$ & 75.5 & 13.2 & 88.9 & 11.3 & 66.3 & 12.2 & 23.6 & 15.5 \\
\hline
\end{tabular}

exceeded by 491, 379, 691 and 700, for Batha, Naseem, Olea and Industrial city, respectively. Yield of broad bean being 16, 13, 21 and $33 \%$ in the four studied areas, respectively, while for kidney bean being 22, 20, 28 and $45 \%$ in the four studied areas, respectively and being 5 , 3,14 and $30 \%$ in the four studied areas, respectively for pea. This reduction in yield is because Maseef was the only locality where the $\mathrm{O}_{3}$ is not exceeded the normal levels but the other ones showed high levels with variable climatic conditions. The results obtained from the present study, which is first of its kind in the region, can be compared with the results obtained from similar studies conducted elsewhere in the world. A study conducted by Posch et al. ${ }^{[33]}$ in the Madrid Area during May-July obtained similar results. In summer 1997, in the Parnish National Park, in the northern outskirts of the Athens Basin, the exceeded damage referred to the critical level of $\mathrm{O}_{3}$ effect on forest trees ${ }^{[36]}$. Above results suggest that the effect of $\mathrm{O}_{3}$ on vegetation is more significant in the Mediterranean area in comparison with northern European sites. The Mediterranean basin is known to have a climate with different characteristics from those of northern and central Europe ${ }^{[18]}$. In spite of this, mapping of the critical level for $\mathrm{O}_{3}$ in Germany shows up to more than $280 \mathrm{~nL} \mathrm{~L}^{-1}$ and the damage was exceeded in $93.7 \%$ of the agricultural area during the period 1991-1995 ${ }^{[6]}$.

In England, cumulative $\mathrm{O}_{3}$ dose for the period of May-July 1989 showed loss exceeding 50\% only on the southwest coast ${ }^{[9]}$. In Toscana (Italy), the long-term critical level of $\mathrm{O}_{3}$ for agricultural crops' cumulative loss is reached to $45 \%$ in almost every year ${ }^{[32]}$.. Previous air filtration experiments conducted in northern Italy and Egypt ${ }^{[1,3,29,35]}$, based on the opentop exposure technique, showed the beneficial effect of filtering ambient air on the productivity of several crops (kidney bean, soybean, barley, bean, radish, pumpkin and wheat). The picture must be regarded as largely incomplete, as dose/response functions for important Italian crops (such as grapevine and vegetables) are not available. Results should be used only as a preliminary indication, considering that the relationships are closely connected to specific climatic and agronomic conditions; furthermore the species sensitivity is 
relative, there being differences in the yield response of cultivars and sometimes of clones ${ }^{24]}$. In addition, differences may exist in responses of plants under different climatic conditions. Crops in northern Europe may be exposed to $\mathrm{O}_{3}$ under conditions of lower temperatures and higher humidity. This could make them more susceptible to $\mathrm{O}_{3}$ effects than crops growing in the Mediterranean area under higher temperatures and lower humidity which could cause more stomatal closure and make crops less susceptible to $\mathrm{O}_{3}$. The economic effects on crops can not be easily derived from equations obtained from OTC experiments because plant response depends on the modifying factors, indicated in level II approach and which are especially important in the Mediterranean area. As the data base for the critical level for crops is based on experiments performed in north Europe, there are many uncertainties about the sensitivity of the Mediterranean species ${ }^{[7]}$. In this area, the proposed long-term critical levels are largely exceeded, but the magnitude of the effects predictable by the dose/response relationship adopted by the UNECE are not reached, suggesting some mitigation mechanisms operating at these latitudes ${ }^{[17]}$. Assigning a value to economic losses from to atmospheric pollution is not an easy question. The main obstacle is the variability of the market price (linked to the elasticity of the demand price) for agricultural products. Furthermore, there are few data relating to losses due to effects of $\mathrm{O}_{3}$ on crop quality ${ }^{[5]}$.

The authors concluded that ozone concentrations over large areas of Riyadh Region have exceeded many times than normal levels and pea is the highly resistant one in such environment than other studied crops. In this region, natural vegetation, agricultural crops and forest trees are likely to be at risk because of the recurrent ambient $\mathrm{O}_{3}$ values. It is difficult to derive the real effects on crops growing in urban/rural sites. More research is needed to understand the way in which the environmental factors may modify that response.

\section{ACKNOWLEDGMENTS}

This study is part of the research activities of the Center of Excellence of Biodiversity Research program, developed and funded by the Ministry of Higher Education. Thanks are expressed to the center and to anonymous referees for their constructive comments on an earlier draft of this paper.

\section{REFERENCES}

1. Ali, A.A., 2003. Improvement of growth and productivity of Phaseolus vulgaris L. grown in open-top chambers under the impact of atmospheric $\mathrm{O}_{3}$ in Egypt. Tackholmia, 23 (1): 179-190.
2. Ali, A.A. and M.H. Salama, 2004. Bioindication study on the effect of ambient $\mathrm{O}_{3}$ on kidney bean plants grown under two irrigation conditions using ethylene-diurea (EDU) at a rural site in Egypt. Egypt. J. Biotech., 16 (2): 27-44.

3. Ali, A.A., 2004. An open-top chamber study to evaluate the impact of airborne pollutants on the growth of pea (Pisum sativum L.) cultivars at three sites of Sharkia province, Egypt. Egypt. J. Biol., 6 (1): 83-92.

4. Ali, A.A. and R.I. Abdel-Fattah, 2006. Protection of agricultural crops in Egypt against adverse effects of atmospheric pollutants, I. by using of ethylene diurea. J. Agron., 5 (1): 158-166.

5. Anguissola Scotti, I., S. Silva and G. Botteschi, 1994. Effects of ozone on grain quality of wheat grown in open-top chambers: 3 years of experimentation. Environ. Pollut., 86: 31-35.

6. Anshelm, F. and T. Gauger, 1999. Mapping Critical Levels for Ozone in Germany. In: Critical Levels for Ozone Level II. Environmental Document no. 115. Swiss Agency for Environment, Forest and Landscape, Fuhrer, J., B. Achermann, (Eds.). Bern, Switzerland, pp: 319324.

7. Ashmore, M. and J. Fuhrer, 1994. Final Report Working Group I. Agricultural crops. In: Critical Levels for Ozone. A UNECE Workshop Report. Fuhrer, J., Achermann, B. (Eds.), Les cahiers de la FAC no. 16, Liebefeld-Bern, Switzerland, pp: 812.

8. Ball, D.J. and R.E. Bernard, 1978. An analysis of photochemical production incidents in the Greater London with particular reference to the summer 1976. Atmospheric Environ., 12: 372-376.

9. Brown, M.J., J.R. Hall, H.M. Dyke, L.D. Emberson, M.R. Ashmore, J.C.I. Kuylenstierna, H.M. Cambridge and S. Cinderby, 1996. Towards a Level II Approach to Mapping the Potential Sensitivity of Wheat to Ozone Concentrations in the UK. In: Critical Levels for Ozone in Europe: Testing and Finalizing the Concepts. Kärenlampi, L. and L. Skärby (Eds.), University of Kuopio, Kuopio, pp: 210-215.

10. Bussottia, F., M. Schaubb, A. Cozzic, N. Krauchib, M. Ferrettic, K. Novakd and J.M. Skellyd, 2003. Assessment of ozone visible symptoms in the field: Perspectives of quality control. Environ. Pollut. 125: 81-89.

11. Cecinato, A., M. Possanzini, A. Liberti and D. Brocco, 1979. Photochemical oxidants in the Rome metropolitan area. Sci. Total Environ., 13: 1-8.

12. Cleveland, W.S. and T.E. Graedel, 1979. Photochemical air pollution in the northeast United States. Science, 264: 1273-1278. 
13. Colbeck, I. and A.R. MacKenzie, 1994. Air Pollution by Photochemical Oxidants. Elsevier Science, Amsterdam, 1994.

14. Deserti, M., S. Cattani and V. Poluzzi, 1998. Il progetto di monitoraggio dell'ozono troposferico (MOTER-MOTRAP) dell'Agenzia Regionale per la Prevenzione e l'Ambiente dell'Emilia Romagna. In: Ozono e Smog Fotochimico. Poluzzi, V., M. Deserti and S. Fuzzi, (Eds.). Maggioli Editore, Rimini, pp: 131-166.

15. Fuhrer, J. and B. Achermann, 1999. Critical Level for Ozone-Level II. Environmental Document no. 115. Swiss Agency for Environment, Forest and Landscape, Bern, Switzerland.

16. Fuhrer, J., L. Skärby and M.R. Ashmore, 1997. Critical levels for ozone effects on vegetation in Europe. Environ. Pollut., 97: 91-106.

17. Fumagalli, I., R. Ambrogi and L. Mignanego, 1999. Ozone in southern Europe: UNECE experiments in Italy suggest a new approach to critical levels. In: Critical Levels for Ozone-Level II. Fuhrer, J., Achermann, B. (Eds.). Environmental Document no. 115. Swiss Agency for Environment, Forest and Landscape, Bern, Switzerland, pp: 239-242.

18. Gimeno, B.S., H. Cabal, C.G. Barquero, B. Artiñano, E. Vilaclara and R. Guardans, 1996. Ozone exceedance maps in Catalunya-Problems and criteria. In: Critical Levels for Ozone in Europe: Testing and Finalizing the Concepts, Kärenlampi, L. and L. Skärby, (Eds.). University of Kuopio, Kuopio, pp: 228-233.

19. Guderian, R., D.T. Tingey and R. Rabe, 1985. Effects of Photochemical Oxidants on Plants. In: Air Pollution by Photochemical Oxidant, Guderian, R. (Ed.). Springer, Berlin, pp: 127-333.

20. Heck, W.W., R.M. Adams, W.W. Cure, A.S. Heagle, H.E. Heggetsad, R.J. Kohat, L.W. Kress, J.O. Rawlings and O.C. Taylor, 1983. A reassessment of crop loss from ozone. Environ. Sci. Technol., 17: 572-581.

21. Heck, W.W., D.T. Tingey and O.C. Taylor, 1988. Assessment of Crop Loss from Air Pollutants. Elsevier Applied Science Publisher, London.

22. Hov, O., I. Allegrini, S. Beilke, R.A. Cox, A. Eliassen, A.J. Elshout, G. Gravenorst, S.A. Penkett and R. Stern, 1987. Evaluation of atmospheric processes leading to acid deposition in Europe. Air Pollution Research Report 10. Commission of European Communties, Brussels.

23. Kärenlampi, L. and L. Skärby, 1996. Critical Level for Ozone in Europe: Testing and Finalizing the Concepts. University of Kuopio, Kuopio.

24. Lefohn, A.S., 1992. Surface Level Ozone Exposures and their Effects on Vegetation. Lewis Publishers, Chelsea, UK.

25. Lorenzini, G., 1999. Le piante e l'inquinamento dell'aria. Edagricole, Bologna.
26. Manning, W.J., 2003. Detecting plant effects is necessary to give biological significance to ambient ozone monitoring data and predictive ozone standards. Environ. Pollut., 126: 375-379.

27. Manning, W.J. and S.V. Krupa, 1992. Experimental Methodology for Studying the Effects of Ozone on Crops and Trees. In: Surface Level Ozone Exposures and their Effects on Vegetation, Lefohn, A.S. (Ed.), Lewis Publishers, Chelsea, MI, USA, pp: 93-156.

28. Manning, W.J. and B. Godzik, 2004. Bioindicator plants for ambient ozone in Central and Eastern Europe. Environ. Pollut., 130: 33-39.

29. Manning, W.J., B. Godzik and R. Musselman, 2002. Potential bioindicator plant species for ambient ozone in forested mountain areas of Central Europe. Environ. Pollut. 119: 283-290.

30. Mathy, P., 1988. The European open-top chambers programme: Objectives and implementation. In: Assessment of Crop Loss from Air Pollutants, Heck, W.W., D.T. Tingey and O.C. Taylor (Eds.). Elsevier Applied Science, London, pp: 505-514.

31. Muzikaa, R.M. R.P. Guyettea, T. Zielonkab and A.M. Liebholdc, 2004. The influence of $\mathrm{O}_{3}, \mathrm{NO}_{2}$ and $\mathrm{SO}_{2}$ on growth of Picea abies and Fagus sylvatica in the Carpathian Mountains. Environ. Pollut., 130: 65-71.

32. Nali, C., C. Pucciariello and G. Lorenzini, 2002. Ozone distribution in central Italy and its effect on crop productivity. Agric. Ecosystems Environ., 90: 277-289.

33. Posch, M., J.P. Hettelingh, P.A.M. de Smett and R.J. Downing, 1997. Calculation and Mapping of Critical Thresholds in Europe. RIVIM Report, The Netherlands.

34. Rey, H.D.L., L.I. de Bauer, J.K. Shibata and N.M. Mendoza, 1986. Impacto de los oxidantes ambientales en el cultivo de frijol, en Montecillos, Estado de Mexico. Agrociencia, 66: 83-95.

35. Schenone, G. and G. Lorenzini, 1992. Effects of regional air pollution on crops in Italy. Agric. Ecosys. Environ., 38: 51-59.

36. Velissariou, D. and L. Skretis, 1999. Critical Levels Exceedances and Ozone Biomonitoring in the Greek Fir Forest (Abies cephalonica Loud.) at the Parnis Mountain National Park in Attica, Greece. In: Critical Levels for Ozone-Level II. Environmental Document no. 115. Swiss Agency for Environment, Fuhrer, J., Achermann, B. (Eds.). Forest and Landscape, Bern, Switzerland, pp: 205-208.

37. Younglove, T., P.M. McCool, R.C. Musselman and M.E. Kahl, 1994. Growth-stage dependent crop yield response to ozone exposure. Environ. Pollut., 86: 287-295. 